Research, part of a Special Feature on Public policies and management of rural forests: lasting alliance or fool's dialogue?

\title{
How to Maintain Domesticity of Usages in Small Rural Forests? Lessons from Forest Management Continuity through a French Case Study
}

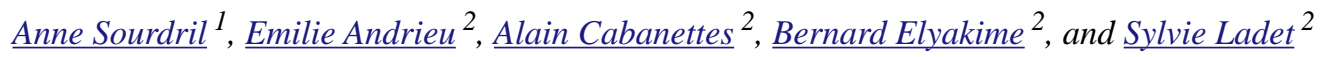

\begin{abstract}
The management of small private forests in the Western World has been under threat owing to rural and agricultural transformations since the Second World War. The actions put in place to preserve those forests are hard to implement because the forests are managed essentially in an unofficial way that is not clearly understood. Through multidisciplinary approaches, our aims were to understand local forest management processes, to assess the continuities and discontinuities of usages and practices in the Coteaux de Gascogne area of France, and to propose guidelines for future forest management. Forest management is shaped by a traditional but unrecognized social system called the house-centered system, which has contributed to a high degree of domesticity and diversity in forestry practices in this area. If forest management guidelines are to be effective, any guidelines put in place should take into account the roots of the traditional management system and attempt to comply with local social organizations. This is a major challenge regarding the long-term preservation of small private forests.
\end{abstract}

Key Words: anthropology; coppice with standards; domestic usage; forestry; history; house-centered system; small private forest; southwestern France

\section{INTRODUCTION}

Contrary to many parts of the world where extensive literature exists on usages and practices in small private forest (e.g., North America and northern Europe: reviewed in Egan 1997, Fischer et al. 2010; Southeast Asia and Africa: Michon et al. 2007), small French private forests are not well known. Indeed, French forested properties of $<25$ ha are generally not managed through official management plans (Plan Simple de Gestion approved by the Centre Régional de la Propriété Forestière, or Regional Center for Forest Property), which are mandatory only for larger properties.

In France, private forests occupy approximately three-quarters of the total forest surface area, which means approximately 11 million ha. These forests belong to a large number of owners (approximately 3.5 million) and are often small: nearly $87 \%$ of the owners possess $<4$ ha (2010 data, Forêt privée française: http://www.foretpriveefrancaise.com). This small property size is a key difference with private forests in North America and northern Europe (Löfman and Kouki 2001, Erickson et al. 2002, Kennedy and Spies 2005). Farmers, whether active or retired, own 1.3 million ha (Cinotti and Normandin 2002), mainly in small woodlots (Maresca and Picard 2010).

Forest management in these small private forests is not described in any document and is poorly known. Usages of trees in these small private forests at the national scale do not seem to be much diversified (Cinotti 1992). The lack of diversity of these usages and associated practices appear to be led by strong changes in French rural areas, linked to agricultural intensification (Cinotti and Normandin 2002). Nevertheless, local management, that we refer to as domestic management (Michon et al. 2007), exist, and usages of small forests, and not only trees, in certain areas (Marty 2004, Sourdril 2008) could be far more diversified than what was observed at the national scale by Cinotti (1992); they should therefore be documented. Moreover, moves for more official regulations are observed from local and global institutions. These could help shape forest management at a regional level, but face strong rejection from woodlot owners (Marty 2000). Policies may nevertheless be needed in a near future, and we point out that policy makers should take into consideration local practices and local contexts if they want to build policies that could meet the needs of the private forest owners.

Here, our goals are to evaluate long-term continuities and discontinuities of usages and practices in small private forests $(<25 \mathrm{ha})$ in the Coteaux de Gascogne area and to propose guidelines for their future management. We present a case study in rural France showing an example of how the understanding of local forest management is fundamental to ensure the future of these forests. We would like to understand more precisely, in a context of socioeconomic change, how a specific social system called the house-centered system (LéviStrauss 1979, Carsten and Hugh-Jones 1995) shapes the forest domestic management in southwestern France. We first describe the system's characteristics and clarify the link between usages and forest practices. We then study the financial potential derived from these usages and practices to verify the economic relevance of this type of management. Finally, we propose management recommendations for small private forests in Coteaux de Gascogne and present the key aspects of institutional foundations that will serve to outline a realistic future for these forests. 


\section{METHODS: ANTHROPOLOGICAL, HISTORICAL, AND FORESTRY APPROACHES}

\section{Study site}

We studied small private forests in southwestern France $\left(43^{\circ}\right.$ $16^{\prime} \mathrm{N}, 48^{\circ} 43^{\prime} \mathrm{E} ; 200-400 \mathrm{~m}$ a.s.l.) in the Long-Term Ecological Research (LTER) platform "Vallées et Coteaux de Gascogne," which covers an area of $440 \mathrm{~km}^{2}$ (Fig. 1). This hilly region is characterized by a temperate climate with oceanic and slight Mediterranean influences. The dominant tree species of the forests are sessile oak (Quercus petraea Lieblein) and pedunculate oak (Q. robur $\mathrm{L}$.). This region is not densely populated ( 19 inhabitants $/ \mathrm{km}^{2}$ ) and is still largely agricultural, with domestic agriculture based on a mixed farming system. Forests are typical of French small private forests (Cinotti 1992, Bessières et al. 2002, Cinotti and Normandin 2002): in southwestern France, properties are small and owned by a large number of people who are mainly active or retired farmers. The management system of these small private forests is traditionally coppice for firewood; some reserved trees, called "standards," might be grown for timber wood.

Fig. 1. Photograph of some of the small private forests included in the case study.

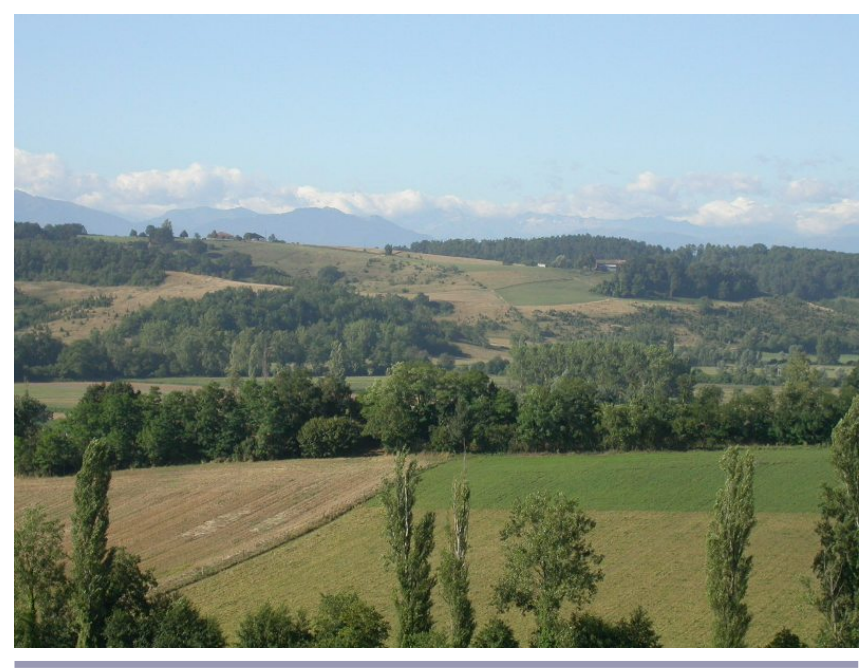

\section{Multidiciplinary approach}

Because of the multiple functions of small private forests, we adopted a multidisciplinary research framework (e.g., Deconchat et al. 2007, Fischer et al. 2010) based on combined anthropological, historical, and forestry approaches using summaries and syntheses of previous methodological works that have the appropriate methodological level upon which to base our conclusions (Sourdril 2008, Elyakime et Cabanettes 2009, Andrieu et al 2011).

An anthropological approach was used mainly in two villages that are representative of the socioeconomic and agricultural situation as well as the landscape and geographical features in the LTER platform. We conducted anthropological interviews and participant observations with 50 owners within the villages and 180 users of the small rural forests, from the entire platform, to obtain an understanding of the social determinants of forest usages since the 1900s, wood-related representations, usages, and knowledge. Analysis of land registries allowed us to understand the means of transmission of 50 properties, all of which included forested land (107 forests for a total of 231 ha), which may affect forest usages (Sourdril 2008).

The historical approach consisted of rebuilding forest management history by geomatic analysis of aerial photos (Institut Géographique National photos taken from 1942 to 2006; Andrieu et al. 2011). This method is accurate but very time consuming, so this analysis has been done for small private forests in a substantial subsample of the study site: 100 ha of forest belonging to 32 owners.

Using individual usages and practices observed on the sites, we evaluated the potential annual flows of values generated on forest sites using a forestry approach. Forestry descriptions were based on the works of Gannevat (1950) and Perrin (1964) and used to model the economy of 1 ha of an individual property of coppices with standards. According to Faustmann's model (Deegen 2000), the value of a forest is assumed to grow like capital invested at compound interest rate.

\section{ONE WOOD PER HOUSE: DIVERSITY OF SMALL PRIVATE FORESTS USAGES}

The shape, usages, and domestic management of small private forests as rural territory organizations in general in the LTER platform are greatly influenced by the presence of a particular social system: système à maison, or house-centered system (Lévi-Strauss 1979, 1983, 1991, Augustins 1989, Cursente 1998), as shown by our anthropological surveys (Sourdril 2008).

The house-centered system is based on a social entity, "the house," defined as a "moral person, keeper of a domain composed altogether of material and immaterial property, which perpetuates itself by the transmission of its name, of its fortune and of its titles in a real or fictive line held as legitimate on the sole condition that this continuity can express itself in the language of kinship or of alliance, and most often, of both together" (Lévi-Strauss 1979 translated by Gillespie 2007:33). House-centered approaches are used by anthropologists in kinship studies throughout the World, e.g., France, Algeria, Indonesia, and South America, to look at the reproduction of social organizations as domestic groups or local societies (Cunningham 1964, Bourdieu 1973, Fox 1987). Researchers are trying to renew house-centered approaches by looking at the house in its material and spatial dimensions (Carsten and Hugh-Jones 1995, Gillespie 2000). If some studies focus on social system's symbolism identification in houses' architectural features (Hamberger 2010), the originality of our 
research is to show how houses shape the usages of the territory.

In southwestern France, social organizations and reproduction of house societies have been described by anthropologists, historians, geographers, and jurists (Le Play 1884, Ott 1981, Augustins et al. 1986, Rogers 1991, Zink 1993, Cursente 1998). House societies are characterized by a real-estate holding transmission system with a single heir who is also successor to the house as an agricultural undertaking (Augustins 1977). The house system model thus leads to the stability of social organization, of real-estate and farm holdings, and of the territory in general (Augustins 1981). This stability that is all the more important because the local social hierarchy is founded on real-estate assets and on two fundamental principles: the ability of the heirs or successors to keep their heritage intact, and their ability to maintain a selfreliant agricultural undertaking (Augustins 1989).

Integral transmission and self-reliant agriculture principles governing houses have great influence on land and forest management. The self-reliance principle requires a diversification of the types of land owned by the house. Each property must have access to meadows, fields, and fallow lands, and also to forested area. This necessity of land diversity, combined with geographical features of the territory, leads to specific spatial organizations in southwestern France. In our study site, estates should be in one piece (Sourdril 2008) and hold all the types of land needed (Sourdril et al. 2012). House estates are then ideally permanent but also highly diverse; this has influence on the forested area, because each house needs to have a small piece of forest, and on the territory in general, because the houses' compositions lead to a highly fragmented landscape (Sourdril 2008).

In the study site, small private forests function similarly to the house (Sourdril 2008): they should assure self-reliance in all products needed by the household and by the farm, and they are divided into areas for firewood, grazing, hunting, and gathering. Forests are managed to provide firewood through coppice every year, to provide timber regularly for the farm framework, and to produce timber to sell, as small private forests are also seen as investment funds. This has resulted in the establishment of coppices with standards, which is a common shape structure of forests in Coteaux de Gascogne. Because the house and forest should be passed on from generation to generation, owners are aware of their responsibility to maintain forest productivity over the long term; in a way, proper forest management is a sign of the house's prosperity.

This anthropological analysis underlines the high degree of domesticity linked to a specific social system that prevailed in small private forests in Coteaux de Gascogne. However, during the last century in particular, this system faced great changes in the rural world such as rural exodus and agricultural abandonment. What, then, will be the future of the forest?

\section{FOREST MANAGEMENT CHARACTERISTICS IN THE CONTEXT OF SOCIAL CHANGE}

To get a precise understanding of changes in forest management, we provide a social analysis of domestic usages of small private forests during the 20th century. We then characterize, for the same period, cuttings in small private forests by highlighting both continuities and discontinuities in management practices. Finally, domestic usages and practices observed in small private forests on the site allow us to assess their financial potential.

\section{Anthropological approach: how to maintain forests' domestic usages?}

Anthropological investigations showed two things. First, small private forest surfaces are mainly permanent and embedded in the house's land following the integral transmission principle (Sourdril 2008). Second, the main domestic usages led by the house's self-reliance principle are maintained through the years in the common structure of coppices with standards.

Owners and users of small private forests still respect the diversity of domestic usages. A farmer owner told us in 2004, "two-thirds of the wood is grazed, the animals keep it clear, one-third with a bit more thickets, the game is left alone in a slightly thicker part. We cut our firewood on the edges, and we keep the trees that have a future [...]. When we see there's a good storm, we don't put the animals in there, to allow the mushrooms to grow." Nevertheless, from around the 1950s, following mechanization, changes in the agricultural production system, and modernization of dwellings, we noticed a decrease in the diversity of wood products needed and a disappearance of some usages such as timber for domestic use; the use of plants, fruits, and sticks; and in-woods grazing.

The main usages, i.e., firewood and construction timber, mushrooming, and private hunting, are continuing to respect the self-reliance principle. Firewood production is still important for private usage, but also sometimes for selling on the black market; some owners do not need as much firewood as they used to because of the generalization of central heating in the 1980 s, but they want to maintain production. This situation is similar to what is happening at the national scale; it has been shown that farmers produce more firewood than professional entrepreneurs (Cinotti and Normandin 2002). At the same time, those owners are trying to favor promising standard trees, not for their own buildings, as metallic structures replaced timber for agricultural buildings in the 1970s, but to sell them to local sawmills or wood entrepreneurs. This is specific to southwestern France, as timber production by farmers has decreased at a national level (Cinotti and Normandin 2000). The owners say that they want to maintain those usages to guarantee their woods' productivity for future generations because they wish the house to be passed on to their heirs. 
Until the 1980s, houses were mostly farms, and heirs were also successors. However, because of agricultural abandonment, heirs sometimes leave the house and village. The consequences for small private forest management are a decrease in the potential manpower for works and, consequently, a decrease in the products collected. Usually, fathers and sons work together in the forest (Sourdril et al. 2006), but with the departure of sons, mutual aid between old generations of neighbors appears to secure production. Those networks come also from the house-centered system, as this system leads to structural forms of mutual aid between neighboring houses for agricultural work or everyday life (Segalen et al. 2010). This situation has allowed the maintenance of domestic usages, but the actual effect of agricultural abandonment threatens forest management. Indeed, until the 2000s, heirs, if not successors, were attached to their estate and followed principles of transmission and selfreliance. Recently, however, there has developed a disinterest by heirs for the property and a progressive splitting of houses without successors, leading to an abandonment of the two principles. Farmland is sold to local farmers, buildings can be sold to nonfarmers, and forests remain the property of the heirs.

The maintenance of forest ownership leads to the adaptation of domestic usages. Firewood can still be collected, but in lower quantities; there is a resurgence in interest in firewood as a potential heating alternative with increases in gas and oil prices. A nonfarmer heir said, "I won't take over the farm. I would like to keep the wood because I have a fireplace at home and we could install an enclosed fireplace to heat the house because with the soaring cost of heating oil, that would always be a way of making savings." We noticed that mushrooms and timber are still collected and contribute to the value of forests. Even forests that are unconnected with houses keep their funds investment character, and mushrooms and timber as valuable goods are signs of their capital value.

Different situations concerning the ownership and management of forests now occur in Coteaux de Gascogne, but what is interesting to underline is that even split from farm or house, forest management has maintained a degree of domesticity that has come from the way house societies organize land. These conceptions are still alive, and we strongly suspect that they will shape forest usages for at least the next two generations of owners who are or will be culturally impregnated by the house's principles, even if the system seem in danger now. Self-reliance and autonomy characterize forest usages even more now, as it seems that when the owners are no longer linked to a house, they transfer their house expectations (transmission, self-reliance, financial returns) to the forest.

In parallel to this anthropological study, we conducted historical investigations to describe and quantify precisely the practices and ways forests have been managed in recent years.

\section{Historical persistence of management practices}

We quantified the characteristics of forestry practices, for example, accurately recording logging areas, by analyzing historical documents such as maps and aerial photographs. First, we estimated the length of forestry cycles to detect changes in cutting frequency in areas that had been harvested in 1942 (approximately 40\% of the area of the studied forests). The main part of the area studied (77\%) is basically subject to 30 -yr periodic harvesting. Indeed, $47.2 \%$ of these areas have been harvested just once since 1942, on average after 33.5 $\pm 18 \mathrm{yr}$. These stands are now mature enough to be harvested again; $30.5 \pm 8$ yr have elapsed since exploitation. A smaller area $(29.8 \%)$ has been harvested twice, on average after 20.7 $\pm 13 \mathrm{yr}$ and then after $28.5 \pm 13 \mathrm{yr}$. These stands are too young to be harvested now $(14.8 \pm 12$ yr have elapsed since they were last harvested), but could be harvested within $15 \mathrm{yr}$. Some smaller areas have been harvested more often: $8.3 \%$ have been harvested three times (on average after $16.9 \pm 11 \mathrm{yr}, 21.2 \pm 11$ $\mathrm{yr}$, and $17.6 \pm 10 \mathrm{yr}$ ), some of which could be harvested again in $10 \mathrm{yr}$; and $0.5 \%$ have been harvested four or five times, but those are mainly areas under high-voltage power lines. It is therefore not possible to draw conclusions about increases in harvesting from the rotation period because the average rotation period was $30 \mathrm{yr}$ and our study covered a 60 -yr period: the second rotation is therefore still in progress. However, $14.1 \%$ of the study area has not been harvested for $64 \mathrm{yr}$, which means that some practices have been abandoned.

The main cutting characteristics have remained constant throughout the period studied (Andrieu et al. 2011): the number of cuts performed each year (4.8 on average), their shape, and spatial aggregation did not show any temporal trend. Nor did we detect any trend in the proportion of cut coppice area, whether they included standards or not: on average since $1942,65 \%$ of the logged area included standards. We nevertheless observed changes in the amount of wood taken: the mean size of cuttings decreased in the 1980s from $0.5 \pm 0.04$ ha before 1980 to $0.2 \pm 0.02$ ha after 1980 . This resulted in a general decrease in the total area harvested each year from 3.8 to $0.8 \mathrm{ha} / \mathrm{yr}$ in the $1942-2006$ period. This smaller amount of wood taken, which has also been observed in other small private forests in our study area (Du Bus de Warnaffe et al. 2006) and more widely in Europe (Peterken 1991), may be related to a reduced need for firewood since the 1980s. However, even though needs have fallen, the tradition of carrying out cuts has survived.

The decrease in logged areas has led to important changes in the structure of small private forests. The current forest management is of low intensity, leading to a general ageing of stands: today, exploitable forest stands cover $60 \%$ of the forest area. However, in the 1940s, the total area cut per year was much greater, and only $6 \%$ of stands were mature and thus exploitable. Lastly, because logging covers small areas and is not very frequent, most of the surface area of small 
private forests has been logged only once or twice since 1942, but completely uncut areas are rare.

The management history of small private forests shows a certain persistence in harvesting practices as well as their adaptation to recent socioeconomic changes. These conclusions confirm and quantify those of the anthropological study: it is certain that there has been a decrease in the area cut, but the tradition of carrying out cuttings has survived. The next step is to determine whether this decrease in the intensity of these forestry practices is related to the intrinsic low economic value of these small rural forests (Fig. 2).

Fig. 2. Understory with cut of coppice for firewood and with reserved oak standards.

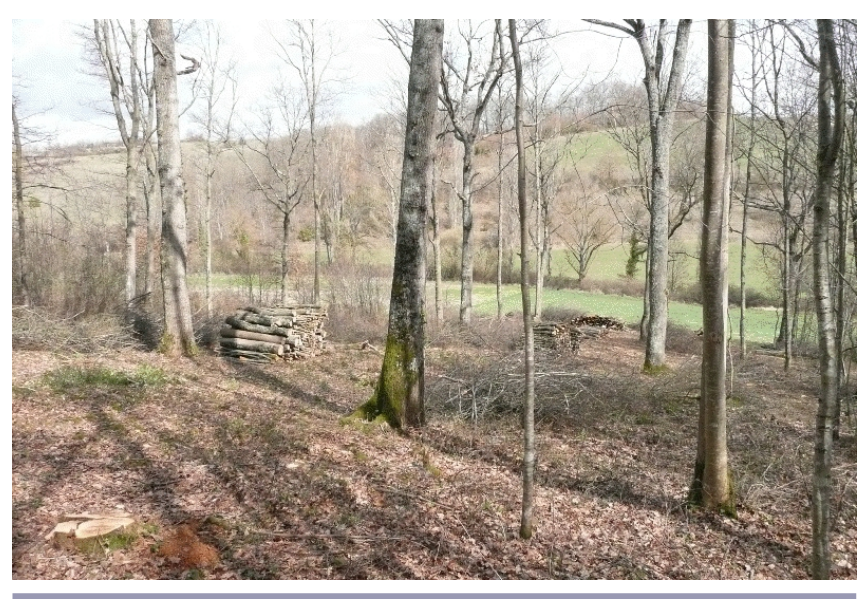

\section{Financial potential of small private forests}

To determine the financial potential of small private forests, we considered a theoretical 1-ha stand of oak coppice with standards as the mean fertility class in the $30-y r$ periodic exploitation described by Perrin (1964) and adapted from Gannevat (1950): every thirty years some trees were kept, up to the maximum age of $150 \mathrm{yr}$. The main usages and practices considered are as defined above: firewood, construction timber, mushrooming, and private hunting.

According to these usages and practices, the standards would provide $93 \mathrm{~m}^{3} /$ ha of valuable construction timber distributed by age class and $72.36 \mathrm{~m}^{3} /$ ha of profitable firewood every thirty years. Coppice would give $75.71 \mathrm{~m}^{3} /$ ha every thirty years, i.e., $2.524 \mathrm{~m}^{3} / \mathrm{yr}$ on $1 / 30$ ha for a hypothetical case of annual firewood cutting. To calculate the corresponding value, we used the average price of wood given by the private French forest owners' magazine La Forêt Privée in 2010. Average prices are given per property for $1 \mathrm{~m}^{3}$ of standing wood, with all harvesting costs deducted.

We sought to obtain a total equivalent average annual potential cash flow generated by 1 ha of the oak coppice-with-standards stand under study. The forest owner receives an annual income from the coppice and an income every thirty years from the construction timber. We took an equivalent annual income generated by the construction timber (for which we calculated the annual interest) and added it to the annual income from the coppice, to which we added the annual income resulting from the amenities (private hunting and mushrooming).

According to the Faustmann model, the forest fund $f$ should work at an $i \%$ compound interest rate for $n$ years to give the fund an associated income of $R_{\mathrm{n}}: f(1+i)^{\mathrm{n}}=f+R_{\mathrm{n}}$, also after $n$ years. First, we calculated the fund's benchmark values by taking real 2010 prices (assumed to be constant). Second, we considered a real average interest rate, $3 \%$, as recommended by If Consultants and Centre National de la Propriété Forestière (2006) for a small forest owner in Coteaux de Gascogne, taking into account the owner's intention to continue to use the forest for domestic purposes. We considered the real average interest rate of $3 \%$ as the best financial opportunity for the fund. Moreover, we used real 2010 prices and interest rates instead of current values to obtain the 2010 benchmark values for funds and the corresponding financial annuities (Table 1): 14,705/((1.03) $\left.)^{30}-1\right)=€ 10,303 /$ ha for the standards fund; $18.83 /\left((1.03)^{1}-1\right)=€ 627.6 /$ ha for the coppice fund. Financial annuities for construction timber or coppice are the interest rates for the corresponding forest funds (Table 1): 0.03 x 10,303=€309/ha for standards. Lastly, it is possible to determine a lump sum for mushrooming and noncommercial hunting amenities by applying a financial rate varying between 1 and $5 \%$ to the forest fund from which those amenities are taken (Table 1): 0.01 to $0.05 \times 10,303=€ 103$ to $515 /$ ha for standards. This estimation is recommended by If Consultants and Centre National de la Propriété Forestière (2006).

The total equivalent average potential annuity obtained would then be relatively high: $€ 437$ to $€ 875$, or $€ 656$ as an average value, for 1 ha. The intrinsic value is sufficiently high for it not to be the cause of a lack of interest in harvesting wood and other nonwood products in the small forests studied. However, because of a decrease in the annual area cut, this intrinsic value is probably higher than the current value. So the future economics of private coppices with standards seems compromised today.

\section{DISCUSSION: RECOMMENDATIONS FOR A "NEW" FORM OF MANAGEMENT}

Usages and practices in the small private forests in Coteaux de Gascogne have been largely shaped by the traditional house-centered system for at least a century, leading to a system of domestic forest management that plays a significant role in shaping forests. However the influence of this system is usually unknown or minimized by official bodies. However, the roots of domestic management should be taken into account if we want to understand forestry practices and/or help 
Table 1. Volumes, prices, values, funds, and annuities for 1 ha of a small woodlot in southwestern France.

\begin{tabular}{|c|c|c|c|c|c|c|c|c|}
\hline Type of wood & $\begin{array}{l}\text { Age class } \\
\quad(\mathrm{yr})\end{array}$ & $\begin{array}{c}\text { Volume of } \\
\text { wood } \\
\left(\mathrm{m}^{3} / \mathrm{ha}\right)\end{array}$ & $\begin{array}{l}\text { Price of } \\
\text { wood } \\
\left(€ / \mathrm{m}^{3}\right)\end{array}$ & $\begin{array}{l}\text { Value of wood } \\
\qquad(€ / \mathrm{ha})\end{array}$ & $\begin{array}{l}\text { Forest fund } \\
\quad(€ / \mathrm{ha})\end{array}$ & $\begin{array}{c}\text { Forest annuity } \\
\left(€ \mathrm{ha}^{-1} \mathrm{yr}^{-1}\right)\end{array}$ & $\begin{array}{l}\text { Amenity annuity } \\
\left(€ \mathrm{ha}^{-1} \mathrm{yr}^{-1}\right)\end{array}$ & $\begin{array}{l}\text { Total annuities } \\
\left(€ \text { ha }^{-1} \mathrm{yr}^{-1}\right)\end{array}$ \\
\hline \multirow{4}{*}{$\begin{array}{l}\text { Construction timber } \\
\text { by age class }\end{array}$} & 150 & 41 & 175 & $41 \times 175$ & - & - & - & - \\
\hline & 120 & 30 & 175 & $30 \times 175$ & - & - & - & - \\
\hline & 90 & 17 & 95 & $17 \times 95$ & - & - & - & - \\
\hline & 60 & 5 & 25 & $5 \times 25$ & - & - & - & - \\
\hline Branches & - & 72.36 & 7.46 & $72.36 \times 7.46$ & - & - & - & - \\
\hline Standards & all & - & - & 14,705 & 10,303 & 309 & $103-515$ & $412-824$ \\
\hline Coppice & 30 & 2.524 & 7.46 & 18.83 & 627.6 & 19 & 6-32 & $25-51$ \\
\hline Total & - & - & - & - & 10,931 & 328 & $109-547$ & $437-875$ \\
\hline
\end{tabular}

owners find solutions for keeping forest management alive in a context of great change in the rural world. This is the major challenge regarding the long-term preservation of small private forests, and it is essential that any policy relative to these forests should understand and satisfy those domestic usages and practices.

In our specific study area, a system of domestic management that meets essential needs, notably firewood and construction timber, continued to predominate during the post-war period and then gradually waned because of increasingly intensive farming practices. Owners, including those who have retired from farming and nonfarmers, have continued to try to respect the principle of self-reliance in the area of forest management and maintain a financial reserve for future generations in their small private forests. They have upheld domestic practices such as cutting firewood, mushrooming, noncommercial hunting, and timber production. However, there is a general decrease in the mean size of cuts. There are two possible outcomes for these small forests: the future generations of owners may lose their ties with these forests and gradually abandon them; or, following the expected rise in the price of fossil fuels, owners may reinvest in wood energy and, in parallel, in other forest usages.

The potential for forest production and the willingness of owners to manage their forests are important factors, but there is a lack of resources and time for dealing with forest usages. Recommendations and local support could help owners to ensure continued management of small private forests. We recommend that policies, if they are to be effective locally, should respect the traditional diversity of usages and domesticity and attempt to comply with local social organizations. For example, traditional neighbor networks could provide a significant source of manpower for working the forests. We recommend that construction programs should be implemented on various levels, using traditional neighbor networks, to share in the exploitation of their woods. This could decrease individual harvesting costs, increase individual benefits, and enable a more intensive exploitation of the woods. Following are examples of such policies.
- Mobilization and even formalization of local networks for forest management groups at the village level: Private owners who manage their small private forests could manage neighboring abandoned parcels through appropriate contractual processes. For example, two forest owners could enter into a contract whereby one would take care of managing the two properties, with the observance of domestic forest usages.

- Creation of local cooperatives for firewood production on the level of the canton (a French administrative division between département and region): We recommend that these private forest owners should be grouped into a new organization taking the farming world as their example. Cooperatives could be created to manage coppices collectively for domestic energy purposes.

- Creation of localized forest development plans for timber management on the scale of the canton or département: New types of cooperation should be considered to ensure better marketing of the construction timber that is not used by the forest owners (Elyakime and Cabanettes 2009). Sales of construction timber could be made as standing timber if subsequent processing, to be paid for by the purchaser, is not excessively expensive. Sales could also be made as cut timber delivered to a storehouse. Harvest costs could then be covered by the seller on the condition that she or he reduces such costs by grouping sales with other forest owners included in forest development plans. Those plans could be examined with the Centre Régional de la Propriété Forestière.

We have observed not only continuities and discontinuities in domestic practices in small private forests, but also benefits. However, the perpetuation of domestic management practices does not seem to be assured or even feasible without new impetus and initiatives from forest owners and public authorities. However, these small forests do have a possible future: Owing to the rise in the price of fossil fuels, small private forest owners are currently reinvesting in wood energy 
uses. References to domestic practices and the traditional social system should provide a way of guaranteeing the future of small private forests in southwestern France. Is this the case in rural Europe and in the western world in general? Other similar studies are essential if we are to answer this question.

Responses to this article can be read online at: http://www.ecologyandsociety.org/voll7/iss2/art6/responses/

\section{Acknowledgments:}

We thank the anonymous reviewers for greatly improving this paper. This work was funded by the Midi-Pyrénées/Aquitaine joint research program "Evolution de la biodiversité de Forêts du Grand Sud Ouest sous l'effet des changements globaux" (Evolution of forest biodiversity in the Greater South West under the effect of global changes), by the French National Agency for Research (ANR) through the "Popular" contract "Politiques publiques et gestions paysannes de l'arbre et de la forêt: alliance durable ou dialogue de dupes?" (Public policies and peasant management of trees and forests: sustainable alliance or a fool's bargain?). Post-doctoral and doctoral grants were awarded by Inra and ACI Sociétés et Cultures dans le Développement, respectively.

\section{LITERATURE CITED}

Andrieu, E., S. Ladet, W. Heintz, and M. Deconchat. 2011. History and spatial complexity of deforestation and logging in small private forests. Landscape and Urban Planning 103 (2):109-117. http://dx.doi.org/10.1016/j.landurbplan.2011.06.005

Augustins, G. 1977. Reproduction sociale et changement social: l'exemple des Baronnies. Revue Française de Sociologie 18(3):465-484. http://dx.doi.org/10.2307/3320968

Augustins, G. 1981. Maison et société dans les Baronnies au XIXème siècle. Pages 20-122 in I. Chiva and J. Goy, editors. Les Baronnies des Pyrénées: maisons, modes de vie, société. Editions de la Maison des Sciences de l'Homme, Paris, France.

Augustins, G. 1989. Comment se perpétuer? Devenir des lignées et destins des patrimoines dans les paysanneries européennes. Société d'Ethnologie, Nanterre, France.

Augustins, G., R. Bonnain, Y. Péron, and G. Sautter, editors. 1986. Les Baronnies des Pyrénées: maisons, espace, famille. Editions de l'Ecole des Hautes Etudes en Sciences Sociales, Paris, France.

Bessières, F., M. Morel, and R. Jean 2002. Structure de la propriété forestière privée en 1999. Agreste, Chiffres et Données 144:1-94.
Bourdieu, P. 1973. The Berber house. Pages 98-110 in M. Douglas, editor. Rules and meanings: the anthropology of everyday knowledge. Penguin, Harmondsworth, UK.

Carsten, J., and S. Hugh-Jones, editors. 1995. About the house: Lévi-Strauss and beyond. Cambridge University Press, Cambridge, UK.

Cinotti, B. 1992. Les agriculteurs et leurs forêts. Revue Forestière Française 4:356-364.

Cinotti, B., and D. Normandin. 2002. Exploitants agricoles et propriété forestière: Où est passée la forêt paysanne? Revue Forestière Française 4:311-328.

Cunningham, C. E. 1964. Order in the Atoni house. Bijdragen tot de Taal-, Land- en Volkenkunde 120(!):34-68.

Cursente, B. 1998. Des maisons et des hommes: la Gascogne médiévale. Presses Universitaires du Mirail, Toulouse, France.

Deconchat, M., A. Gibon, A. Cabanettes, G. du Bus de Warnaffe, M. Hewison, E. Garine, A. Gavaland, J.-P. Lacombe, S. Ladet, C. Monteil, A. Ouin, J.-P. Sarthou, A. Sourdril, and G. Balent. 2007. How to set up a research framework to analyze social-ecological interactive processes in a rural landscape. Ecology and Society 12(1): 15. [online] URL: http://www.ecologyandsociety.org/vol12/iss1/art15.

Deegen, P. 2000. Concerning the interpretation of the Faustmann's formula as a complex behavioral model in forest economics. Allgemeine Forst- und Jagdzeitung 171 (5-6):88-96.

Du Bus de Warnaffe, G., M. Deconchat, S. Ladet, and G. Balent. 2006. Variability of cutting regimes in small private woodlots of south-western France. Annals of Forest Science 63(8):915-927. http://dx.doi.org/10.1051/forest:2006075

Egan, A. F. 1997. From timber to forests and people: a view of nonindustrial private forest research. Northern Journal of Applied Forestry 14(4):189-193.

Elyakime, B., and A. Cabanettes. 2009. How to improve the marketing of timber in France? Forest Policy and Economics 11(3):169-173. http://dx.doi.org/10.1016/j.forpol.2009.01.001

Erickson, D. L., R. L. Ryan, and R. De Young. 2002. Woodlots in the rural landscape: landowner motivations and management attitudes in a Michigan (USA) case study. Landscape and Urban Plan 58(2-4):101-112. http://dx.doi.or $\mathrm{g} / 10.1016 / \mathrm{S} 0169-2046(01) 00213-4$

Fischer, A. P., J. Bliss, F. Ingemarson, G. Lidestav, and L. Lönnstedt. 2010. From the small woodland problem to ecosocial systems: the evolution of social research on smallscale forestry in Sweden and the USA. Scandinavian Journal 
of Forest Research 25(4):390-398. http://dx.doi.org/10.1080/ $\underline{02827581.2010 .498386}$

Fox, J. J. 1987. The house as a type of social organization on the Island of Roti. Pages 171-191 in C. Macdonald, editor. De la hutte au palais: sociétés "à maison » en Asie du Sud-est insulaire. CNRS, Paris, France.

Gannevat, F. 1950. Courbes et tables de croissance. Revue Forestière Française 4:223-226. http://dx.doi.org/10.4267/20 42/27674

Gillespie, S. D. 2000. Beyond kinship: an introduction. Pages 1-22 in S. D. Gillespie, editor. Beyond kinship: social and material reproduction in house societies. University of Pennsylvania Press, Philadelphia, Pennsylvania, USA.

Gillespie, S. D. 2007. When is a house? Pages 25-50 in R. A. Beck, Jr., editor. The durable house: house society models in archaeology. Occasional Paper 35. Center for Archeological Investigations Occasional Paper 35. Southern Illinois University, Carbondale, Illinois, USA.

Hamberger, K. 2010. La maison en perspective: un modèle spatial de l'alliance. L'Homme 194:7-40.

If Consultants and Centre National de la Propriété Forestière. 2006. Les aménités forestières en Midi-Pyrénées. Direction Générale de l'Agriculture et de la Forêt de Midi-Pyrénées, Gragnague-Toulouse, France.

Kennedy, R. S. H., and T. A. Spies. 2005. Dynamics of hardwood patches in a conifer matrix: 54 years of change in a forested landscape in coastal Oregon, USA. Biological Conservation 122(3):363-374. http://dx.doi.org/10.1016/j.bio con.2004.07.022

La Forêt Privée. 2010. Cours des bois sur pied. La Forêt Privée 11-12:50-51.

Le Play, F. 1884. L'organisation de la famille selon le vrai modèle signalé par l'histoire de toutes les races et tous les temps. A. Marne, Tours, France.

Lévi-Strauss, C. 1979. La voie des masques. Plon, Paris, France.

Lévi-Strauss, C. 1983. Histoire et ethnologie. Annales, Histoire, Sciences Sociales 38(6):1217-1231. http://dx.doi.org /10.3406/ahess.1983.411017

Lévi-Strauss, C. 1991. Maison. Pages 434-436 in P. Bonte and M. Izard, editors. Dictionnaire de l'ethnologie et de l'anthropologie. PUF, Paris, France.

Löfman, S., and J. Kouki. 2001. Fifty years of landscape transformation in managed forests of southern Finland. Scandinavian Journal of Forest Research 16(1):44-53. http:// dx.doi.org/10.1080/028275801300004406

Maresca, B., and R. Picard. 2010. Les propriétaires forestiers sont attachés à leur patrimoine mais peu motivés par son exploitation commerciale. Consommation et Modes de Vie 228.

Marty, P. 2000. Le côté obscur de l'espace: pour une application d'anti-monde à la forêt privée. L'Espace Géographique 2:137-149.

Marty, P. 2004. Forêts et sociétés. Logiques d'action des propriétaires privés et production de l'espace forestier, l'exemple du Rouergue. Publications de la Sorbonne, Paris, France.

Michon, G., H. de Foresta, P. Levang, and F. Verdeaux. 2007. Domestic forests: a new paradigm for integrating local communities' forestry into tropical forest science. Ecology and Society 12(2): 1. [online] URL: http://www.ecologyands ociety.org/vol12/iss2/art1.

Ott, S. 1981. The circle of mountains: a Basque shepherding community. University of Nevada Press, Reno, Nevada, USA.

Perrin, H. 1964. Sylviculture: le traitement des forêts. Volume 2. Ecole Nationale des Eaux et Forêts, Nancy, France.

Peterken, G.F. 1991. Managing semi-natural woods: a suitable case for coppice. Quarterly Journal of Forestry 85:21-29.

Rogers, S. C. 1991. Shaping modern times in rural France: the transformation and reproduction of an Aveyronnais community. Princeton University Press, Princeton, New Jersey, USA.

Segalen, M., S. Chevalier, G. Augustins, V. Manceron, L. Amiotte-Suchet, and A. Sourdril. 2010. Three French localities. Pages 169-224 in P. Heady and P. Schweitzer, editors. Family, kinship and state in contemporary Europe, vol. 2. The view from below: nineteen localities. Campus Verlag, Frankfurt, Germany.

Sourdril, A. 2008. Territoire et hiérarchie dans une société à maison Bas-Commingeoise: permanence et changement. Dissertation. University of Paris X, Nanterre, France.

Sourdril, A., M. Deconchat, and S. Ladet. 2012. Perpétuer l'organisation de son territoire en situation de changement: le cas d'une société à maison du sud-ouest de la France. Bulletin de liaison des sociétés savantes du CTHS. Langues, communautés et territoires en France aujourd'hui: recherches et enquêtes en ethnologie et en linguistique 14:146-159. [online] URL: http://www.cths.fr/ files/an/pdf/bulletin 14.pdf

Sourdril, A., G. du Bus de Warnaffe, M. Deconchat, and G. Balent. 2006. From farm forestry to farm and forestry in southwestern France as a result of changes in a 'house-centred' social structure. Small-Scale Forest Economics, Management and Policy 5(1):127-144.

Zink, A. 1993. L'héritier de la maison: géographie coutumière du sud-ouest de la France sous l'Ancien Régime. Editions de l'Ecole des Hautes Etudes en Sciences Sociales, Paris, France. 